Opinion

\section{How can we develop immunity against COVID-19 and defeat it}

\author{
Pramod Stephen* \\ Innovator, Christian Church, PO: 845456, Bihar, India
}

\section{Summary}

We know that Corona Virus develops in animals, birds and humans' body. Now it is a pandemic and many people are dying with each passing day and a number of patients are increasing every hours. If we do not control it then it is dangerous for humanity. As we know that incubation period for COVID-19 is 1 to 14 days and it's live in the environment for 12 to 14 hours. The only solution to spread of virus is by social distancing. As we know that it affects person with low immunity so it is advised for all people to have balance diet, exercise daily and spend time in meditation for increasing immunity. I want to share a natural method to develop and increase the immunity power by the bile juice of animals, birds and we can try for corona virus too.

\section{More Information}

*Address for Correspondence: Pramod Stephen, Innovator, Christian Church, PO Sugauli 845456, Bihar, India,

Email: Pramod_stephen@rediffmail.com

Submitted: 10 April 2020

Approved: 13 April 2020

Published: 14 April 2020

How to cite this article: Stephen P. How can we develop immunity against COVID-19 and defeat it. Insights Clin Cell Immunol. 2020; 4 : 003-004.

\section{DOI: 10.29328/journal.icci.1001013}

Copyright: (c) 2020 Stephen P. This is an open access article distributed under the Creative Commons Attribution License, which permits unrestricted use, distribution, and reproduction in any medium, provided the original work is properly cited.

\section{D) Check for updates}

OPEN ACCESS

\title{
Structure of covid-19
}

It is composite protein/glycan shield by cryo.

\section{How it's work}

As we know that it is shield by proteins and glycan and bile juice breaks the protein and fats and supports digestion in small intestine and Ethyl alcohol/rectified spirit kills the virus. If we use this combination then people will get strength and bile juice works as a stem cells and rapidly runs in blood. It helps in reducing blood sugar level and fats in the blood as it boosts functions of Pancreas, liver and improves metabolism.

\section{Material and Method}

Take an animal, bird and fish chopped bile juice and mixed it with 50\% Bile juice and 50\% ethyl alcohol/rectified spirit and shake well in a bottle and keep it for 12 hours and after 12 hours all particles will sit at the bottom and we can use 1 drop upper site extract by oral administration. And repeated dose along with other drugs, it can develop immunity because I use it and found fruitful result in cough cold and digestion. I hope that it will kill all kind of Virus and people will recover from this deadly virus. It is my humble request to WHO and every Government agency to experiment on this topic and save the world by COVID-19.

Note: We can use $50 \%$ ethyl alcohol and $50 \%$ bile juice and mix and give to critical patients for experiment. I have attached the report from Central Drug Research Institute Lucknow about Analysis of substance that no harmful substance is present in it. Although the taste is bitter but it is lifesaving in critical circumstances and vaccines can be made using this composition.

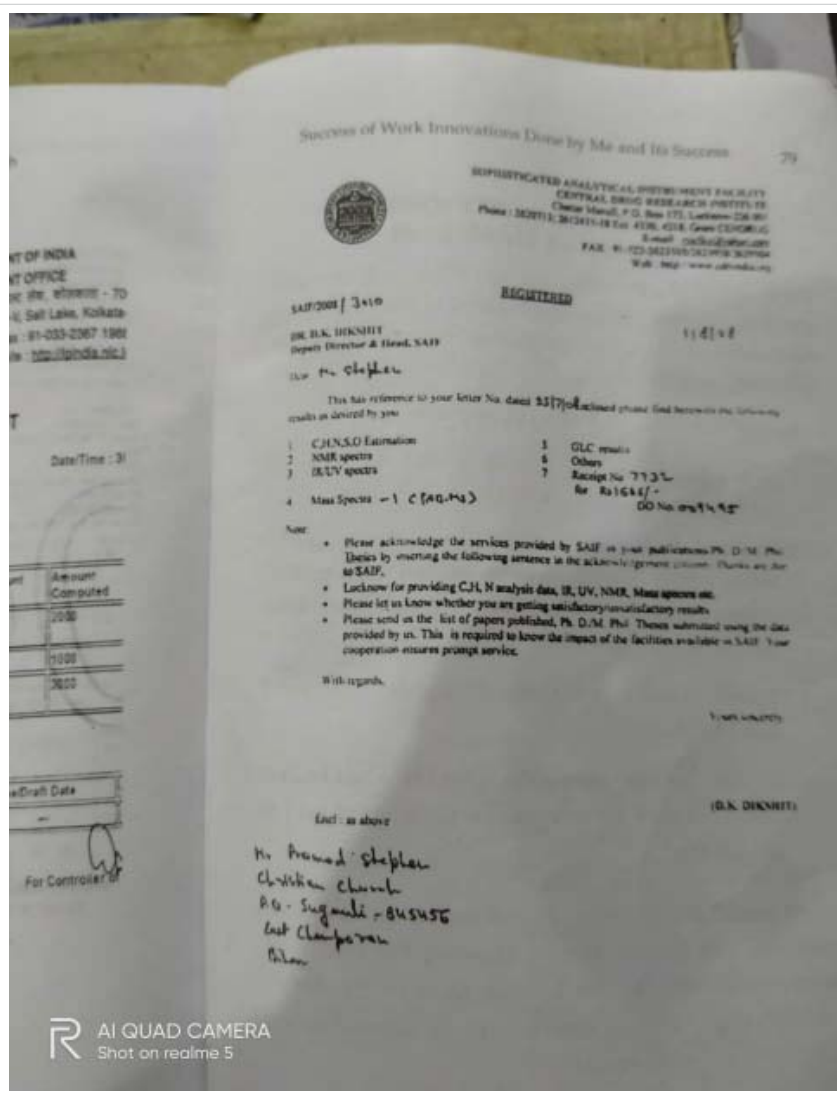




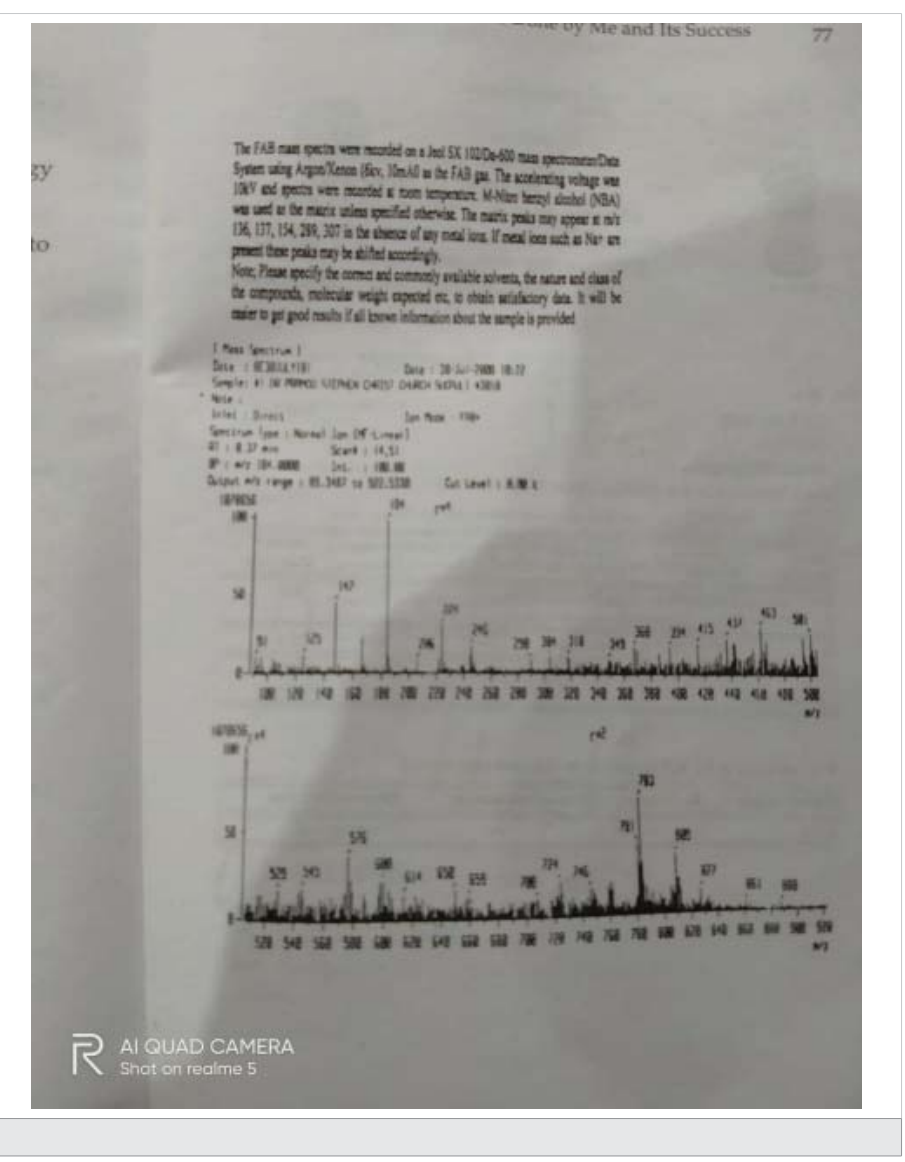

